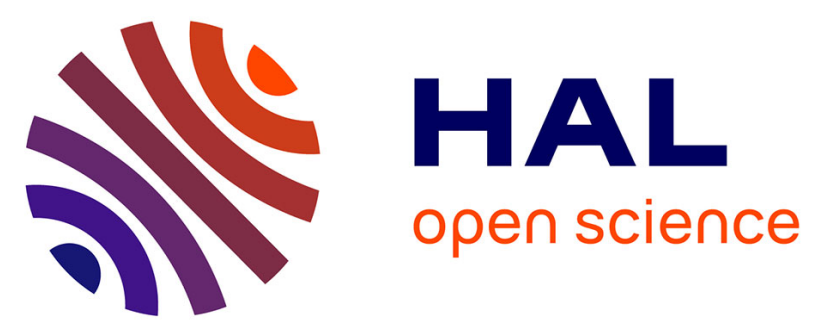

\title{
A scientific note on E- $\beta$-ocimene, a new volatile primer pheromone that inhibits worker ovary development in honey bees
}

\author{
Alban Maisonnasse, Jean-Christophe Lenoir, Guy Costagliola, Dominique \\ Beslay, Fanny Choteau, Didier Crauser, Jean-Marc Becard, Erika Plettner, \\ Yves Le Conte
}

\section{To cite this version:}

Alban Maisonnasse, Jean-Christophe Lenoir, Guy Costagliola, Dominique Beslay, Fanny Choteau, et al. A scientific note on E- $\beta$-ocimene, a new volatile primer pheromone that inhibits worker ovary development in honey bees. Apidologie, 2009, 40 (5), pp.562-564. 10.1051/apido/2009024 . hal00892031

\section{HAL Id: hal-00892031 \\ https://hal.science/hal-00892031}

Submitted on 1 Jan 2009

HAL is a multi-disciplinary open access archive for the deposit and dissemination of scientific research documents, whether they are published or not. The documents may come from teaching and research institutions in France or abroad, or from public or private research centers.
L'archive ouverte pluridisciplinaire HAL, est destinée au dépôt et à la diffusion de documents scientifiques de niveau recherche, publiés ou non, émanant des établissements d'enseignement et de recherche français ou étrangers, des laboratoires publics ou privés. 


\title{
A scientific note on $\mathrm{E}$ - $\beta$-ocimene, a new volatile primer pheromone that inhibits worker ovary development in honey bees*
}

\author{
Alban MaISONNASSE${ }^{1}$, Jean-Christophe LenOIR ${ }^{1}$, Guy COSTAGLIOLA ${ }^{2}$, Dominique BeSLAY ${ }^{1}$, \\ Fanny Choteau ${ }^{1}$, Didier Crauser ${ }^{1}$, Jean-Marc Becard ${ }^{1}$, Erika PleTtNeR ${ }^{3}$, Yves Le ConTE ${ }^{1}$ \\ ${ }^{1}$ INRA, UMR 406, Abeilles et Environnement, Laboratoire Biologie et Protection de 1'Abeille, Site Agroparc, 84914 \\ Avignon, France \\ ${ }^{2}$ INRA, Unité Plantes et Systèmes de culture Horticoles, Site Agroparc, 84914 Avignon, France \\ ${ }^{3}$ Department of Chemistry, Simon Fraser University, 8888 University Drive, Burnaby, B.C. V5A 1S6, Canada
}

Received 28 October 2008 - Revised 27 January 2009 - Accepted 3 February 2009

E- $\beta$-ocimene / ovary development / pheromone / brood / Apis mellifera

In social insects, larvae are completely dependent on adults to complete their development. In honey bees (Apis mellifera L.), larval development requires that larvae engage workers in nursing tasks rather than allocating energy in other activities (Le Conte and Hefetz, 2008). Indeed, in the absence of any constraint, workers tend to become active reproductive individual. The queen inhibits worker ovary development via pheromones (Hoover et al., 2003; Wossler and Crewe, 1999), but the inhibition of worker ovary development seems superior when bees are exposed to unsealed brood (Kropacova and Haslbachova, 1970, 1971). Components of the brood pheromone have already been identified and consist of a blend of 10 esters (Le Conte et al., 1989, 1990). Two of these low volatility compounds have been demonstrated to partially decrease worker ovary development (Mohammedi et al., 1998; Pankiw and Garza, 2007). Thus, we asked whether brood emits volatile compounds that could also have an effect on worker ovary activation. We identified a new highly volatile molecule from the larvae $\mathrm{E}-\beta$-ocimene, that inhibits worker ovary maturation.

We used Solid Phase Microextraction (SPME) (65 $\mu$ m Carbowax) to sample volatiles emitted by different larval instars. We analyzed 20 larvae at stage $1,2-3$ or 10 larvae at stage 4-5. Larvae were kept in a $15 \mathrm{~mL}$ closed vial for $20 \mathrm{~min}$ in an incubator at $34{ }^{\circ} \mathrm{C}$ and $50 \%$ humidity $(\mathrm{N}=8$,

Corresponding author: Alban Maisonnasse, alban.maisonnasse@avignon.inra.fr

* Manuscript editor: Stan Schneider
10 and 7 biological replicates, respectively) during the sampling. Afterward, the fiber was desorbed into a gas chromatograph (Varian-Chrompack CPSil 8 CB-MS $30 \mathrm{~m} \times 0.25 \mathrm{~mm}$ column with the following parameters: column temperature $40{ }^{\circ} \mathrm{C}$ for $2 \mathrm{~min}$, then $40{ }^{\circ} \mathrm{C}$ to $200{ }^{\circ} \mathrm{C}$ at $30{ }^{\circ} \mathrm{C} \cdot \mathrm{min}^{-1}$, and $200{ }^{\circ} \mathrm{C}$ to $320^{\circ} \mathrm{C}$ at $10^{\circ} \mathrm{C} \cdot \mathrm{min}^{-1}$ ). Chromatograms showed different peaks but the only major compound found in all samples was $\mathrm{E}-\beta$-ocimene (3(E)3,7-dimethyl-1,3,6-octatriene identified by GC-MS and confirmed by a chemical standard). We determined that one larva produces in 20 minutes 2.84 , 12.4 and $0.40 \mathrm{ng}$ of $\mathrm{E}-\beta$-ocimene at stage $1,2-3$ and $4-5$, respectively (Fig. 1A) This compound is thus emitted in a significantly higher quantity by $2-$ 3 larval instars compared to first and final instars (Kruskal-Wallis ANOVA test, $\mathrm{N}=25, \chi^{2}=18.99$, $d f=2, P<0.001$; stage 1 vs. $2-3$ : Mann-Whitney $\mathrm{U}$ post-hoc test, $\mathrm{Z}=-3.4208, P<0.001$ and stage $2-3$ vs. $4-5: \mathrm{Z}=3.4157, P<0.001)$. Older larvae have a lower level of $\mathrm{E}-\beta$-ocimene production than first instars larvae $(\mathrm{Z}=3.2404, P=0.0012)$ despite being from 225 to 400 times bigger (Jay, 1963). A test in natural condition was done and $\mathrm{E}-\beta$-ocimene was also found on larvae kept on their cells.

We then tested whether E- $\beta$-ocimene produced by larval instars 2-3 inhibits worker ovary development. Groups of 100 bees obtained from a mix of 3 colonies were tested. Bees were kept in Pain cages $(11 \times 8.5 \times 5.8 \mathrm{~cm})($ Pain, 1966) from emergence until 15 days of age. Due to its high volatility and in order to avoid saturation of E- $\beta$-ocimene in cages, we mixed the molecule with paraffin oil and verified with SPME that a 10 larvae equivalent/caged bee 

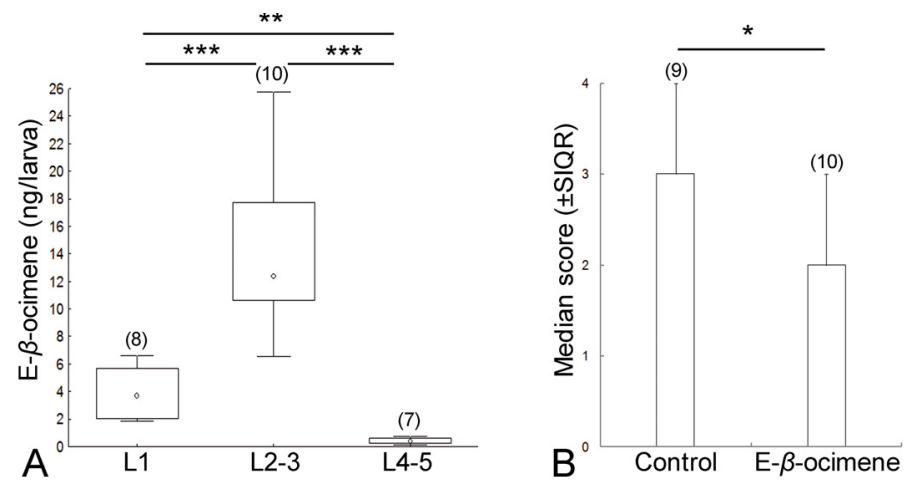

Figure 1. (A) E- $\beta$-ocimene production by different larval instars during 20 minutes using an external standard method of quantification. (ng/larva) (circle: median; box: 25\%-75\%; whisker: Min-Max). (B) Level of ovary development in response to 10 larval equivalents per bee of $\mathrm{E}-\beta$-ocimene $(9 \mu \mathrm{g}$ of $\mathrm{E}-\beta$-ocimene/bee/ 24 hrs) (median \pm Semi-InterQuartile Range). (number of sampled groups in brackets).

of $\mathrm{E}-\beta$-ocimene slowly dissipated over 24 hours (ie. 900 ug of E- $\beta$-ocimene/cage/24 hours). So, in each cage we then created an environment of 1000 larvae equivalent of $\mathrm{E}-\beta$-ocimene. The $\mathrm{E}-\beta$-ocimene and paraffin mix was placed in a wire screen-covered petri-dish at the bottom of the cage so that the bees could never be in direct contact with the molecule. Caged workers were kept at $34{ }^{\circ} \mathrm{C}$ in the dark and fed with a honey-sucrose candy, fresh pollen and water ad libitum. We performed 10 replicates for treatment and 9 per control (paraffin only). We used two identical incubators, one for treatment cages and one for control cages, to prevent E- $\beta$-ocimene dispersion. For each cage, 20 bees were randomly chosen, dissected, and the level of ovary development was determined using the 5 point scale ovary classification of Pernal and Currie (2000). Ovaries were classified as following: stage 0: no follicle development, stage 1: slight enlargement, stage 2: presence of distinct cells leading to swellings and constrictions, stage 3 egg volume exceeding that of the nutritive follicle, stage 4: presence of fully formed eggs.

$\mathrm{E}-\beta$-ocimene treatment significantly inhibited worker ovary development compared to workers exposed to untreated paraffin control (Fig. 1B. MannWhitney $U$ test on the mean score of each cage, $\mathrm{N}=19, \mathrm{Z}=-2.168, P=0.0301)$. The results support our hypothesis that this compound acts as a volatile primer pheromone on workers by inhibiting maturation of their ovaries. By emitting E- $\beta$-ocimene, larvae may prevent workers (more precisely nurses) from allocating resources into egg production but rather take care of them.
This compound also has been detected in mated honey bee queens (Gilley et al., 2006), and was present in lower amounts in queens who were rejected within the first week of their introduction into queenless colonies (DeGrandi-Hoffman et al., 2007). Queen-produced E- $\beta$-ocimene may then play a role in her ability to regulate worker ovary development, and thus, help her to monopolize egglaying. Further studies should be done to test for synergistic effects between $\mathrm{E}-\beta$-ocimene, brood and queen pheromones on worker ovary activation. Another important question to disentangle would be to understand the variation in the production of $\mathrm{E}-\beta$ ocimene observed in successive larval instars. One could hypothesize that $\mathrm{E}$ - $\beta$-ocimene also acts as a hunger signal during starvation stress. Young larvae which produce more $\mathrm{E}-\beta$-ocimene than older larvae could have a higher need of food.

\section{ACKNOWLEDGEMENTS}

We thank Thomas and Martin Le Conte, for their technical help and Marion Ellis that reviewed the English of our text. This work was supported by Famille Mary founds and Human Frontier Science Program (RGP0042/2007-C101).

Note scientifique sur une nouvelle phéromone modificatrice volatile qui inhibe le développement ovarien des abeilles, le E- $\beta$-ocimene. 


\section{Eine wissenschaftliche Notiz über E- $\beta$-ocimene, ein neues flüchtiges Primer-Pheromon, das die Ovarentwicklung der Honigbienen hemmt.}

\section{REFERENCES}

DeGrandi-Hoffman G., Gilley D., Hooper J. (2007) The influence of season and volatile compounds on the acceptance of introduced European honey bee (Apis mellifera) queens into European and Africanized colonies, Apidologie 38, 230-237.

Gilley D.C., DeGrandi-Hoffman G., Hooper J.E. (2006) Volatile compounds emitted by live European honey bee (Apis mellifera L.) queens, J. Insect Physiol. 52, 520 527.

Hoover S.E.R., Keeling C.I., Winston M.L., Slessor K.N. (2003) The effect of queen pheromones on worker honey bee ovary development, Naturwissenschaften 90, 477480 .

Jay S.C. (1963) The development of honeybees in their cells, J. Apic. Res. 2, 117-134.

Kropacova S., Haslbachova H. (1970) The development of ovaries in worker honeybees in queenright colonies examined before and after swarming, J. Apic. Res. 9, 6570.
Kropacova S., Haslbachova H. (1971) The influence of queenlessness and of unsealed brood on the development of ovaries in worker honeybees, J. Apic. Res. 10, 57-61.

Le Conte Y., Hefetz A. (2008) Primer pheromones in social hymenoptera, Annu. Rev. Entomol. 53, 523-542.

Le Conte Y., Arnold G., Trouiller J., Masson C., Chappe B. (1990) Identification of a brood pheromone in honeybees, Naturwissenschaften 77, 334-336.

Le Conte Y., Arnold G., Trouiller J., Masson C., Chappe B., Ourisson G. (1989) Attraction of the parasitic mite varroa to the drone larvae of honey bees by simple aliphatic esters, Science 245, 638-639.

Mohammedi A., Paris A., Crauser D., Le Conte Y. (1998) Effect of aliphatic esters on ovary development of queenless bees (Apis mellifera L.), Naturwissenschaften 85, 455-458.

Pain J. (1966) Nouveau modèle de cagettes expérimentales pour le maintien d'abeilles en captivité, Ann. Abeille 9 , 71-76.

Pankiw T., Garza C. (2007) Africanized and European honey bee worker ovarian follicle development response to racial brood pheromone extracts, Apidologie 38, 156163.

Pernal S.F., Currie R.W. (2000) Pollen quality of fresh and 1year-old single pollen diets for worker honey bees (Apis mellifera L.), Apidologie 31, 387-409.

Wossler T.C., Crewe R.M. (1999) Honeybee queen tergal gland secretion affects ovarian development in caged workers, Apidologie 30, 311-320. 